\title{
THE INTERNATIONAL LABOUR MOVEMENT AND THE LIMITS OF INTERNATIONALISM: THE INTERNATIONAL SECRETARIAT OF NATIONAL TRADE UNION CENTRES, 1901-1913
}

Summary: Despite an abundance of literature on the Second International relatively little is known about the work of the International Secretariat of National Trade Union Centres (ISNTUC). Founded in 1901 by the German and Scandinavian labour leaders, this exclusively trade union International (the forerunner of the post-war International Federation of Trade Unions) included representatives of most of the major labour movements of Europe and the USA. Under German leadership it occupied itself with exclusively trade union issues, a limitation which was contested by revolutionary labour federations. Study of the ISNTUC therefore reveals much about conceptions of internationalism within the internationally organized labour movement.

The question of the "collapse" of labour and socialist internationalism in August 1914 has continued to preoccupy historians, who have attempted to explain why it was that, despite the pronouncements of the Second International and the evident support which this organization mustered for its antiwar demonstrations, there was no significant workers' resistance to the outbreak of war. As Jolyon Howorth has already pointed out in his discussion of the major approaches to this question of the breakdown of workers' internationalism in $1914,{ }^{1}$ however, traditional historiography has tended to obscure several crucial problems. In particular, the overlap between international socialism and internationally organized labour is blurred. By concentrating on either the pronouncements and activities of the Second International, on one level, or on the behaviour of individual national labour movements, on another level, the assumption is made that these two aspects make up the complete picture. the Second International is thus seen as the automatic extension of national labour organization, reflecting a Marxist view of the party/trade union relationship.

\footnotetext{
1 Jolyon Howorth, "French Workers and German Workers: The Impossibility of Internationalism, 1900-1914", European History Quarterly, Vol. 15 (1985), no. 1, pp. 71-97. The reader is referred to Jolyon Howorth's analysis of existing literature on the subject, since it is not proposed to re-evaluate it here.
} 
A discussion of Marx's views on trade organizations and their relationship to the socialist movement is problematic, ${ }^{2}$ but it is clear that Marx thought that the labour movement, organized around economic demands, could have no lasting success unless it allied itself with the political (socialist) movement. ${ }^{3}$ Within the Second International, however, there were conflicting views on the role of trade unions, which were not resolved, but rather highlighted, by the decision to impose recognition of political action. The Second International itself never solved this problem in a satisfactory manner and indeed Leninist historiography sees in the failure of the Second International to block reformism, by subordinating trade union demands to a radical socialist analysis, a major cause of the breakdown of international socialism in $1914 .^{4}$

That the Second International itself never resolved the central problem of the party/union relationship serves to underline the sensitive nature of the question. Indeed, how could the question be other than sensitive when it was at the heart of the wider debate which opposed revolution and reform? Put quite simply the question was this: could organizations which rejected or played down revolutionary solutions in favour of working within the existing social framework to gain satisfaction of immediate demands (higher wages, improved working conditions, protective legislation) be reconciled with groups which saw workers' emancipation as the result of socialist conquest of political power? This dilemma was at the heart of debates between trade unions and political parties within the Second International. To some extent the question arose even in those trade unions which did not reject revolutionary solutions. The French Confédération Générale du Travail (CGT), for instance, formulated the theory of the "double task" of trade unionism in order to situate partial reforms within an overall revolutionary strategy. ${ }^{5}$ It was a convenient formula which failed to

${ }^{2}$ Since Marx has left behind no systematic study of this question, it has been open to interpretation. See Karl Marx and Friedrich Engels, Le Syndicalisme, 2 volumes (Paris, 1972) and Richard Hyman, Marxism and the Sociology of Trade Unionism (London, 1975) on this. Georges Haupt has reflected on the importance and the complexity of the debate on party/ trade-union relationship in the Second International in "Socialisme et syndicalisme. Les rapports entre partis et syndicats au plan international: une mutation?", Jaurès et la classe ouvrière (Paris, 1981).

${ }^{3}$ See, for example, Marx's Instructions to the Geneva delegates on "The Past, Present and Future of Trade Unions", Collected Works, Volume 20, pp. 191-192, and Marx, Value, Price and Profit (also known as Wages, Prices and Profit), ibid., Volume 20, pp. 101-150.

4 This argument is expounded by Angelika Klein in her Ph.D. dissertation, "Das Verhältnis von Partei und Gewerkschaften in der II. Internationale (1900-1914)" (Martin-Luther-Universität, Halle, 1978).

$s$ The resolution on trade unions and parties passed at the CGT's Amiens congress in 1906 and known as the "Charte d'Amiens" speaks of a "double besogne": the daily task of protests and demands, and the final goal of total emancipation. See CGT, XVe Congres national corporatif (IXe de la Confédération), tenu à Amiens du 8 au 16 octobre 1906. Compte rendu des travaux (1906), pp. 170-171. 
acknowledge that there might sometimes be a contradiction between the two sets of objectives involved.

The debate on nationalism and internationalism is similarly problematic. In its desire to emphasize the positive aspects of internationalism, the Second International tended to gloss over the question of nationalism and the working class. Nor did Marx and Engels offer a systematic theory of nationalism and internationalism which could have guided the work of the Second International. ${ }^{6}$ Internationalism was seen as a logical product of working-class consciousness and, as such, its power was never questioned, even when socialists acknowledged the reality of the nation and its strategic importance in the political struggle. In fact, as we shall see, it is difficult to speak of labour internationalism as a coherent entity, given the diversity of conceptions of internationalism and international activity amongst the labour movements concerned, and given that questions of labour were considered to be more important than questions of internationalism. The beauty of Marx's rallying cry to "Workers of all lands" to unite was precisely that it could appeal to disparate groups with different conceptions of international activity. Yet it meant nothing to workers unless it was tied in with questions directly concerning the world of work.

Thus, when the first international labour association was formed in 1864, the impetus came directly from workers' experiences. The First International, which served as a framework of reference for many different groups later, came about as a result of ties between French and English workers, in an attempt to strengthen mutual solidarity through financial and moral support during strikes. It was hoped that international association could prevent the employers' practice (especially in Britain) of bringing in foreign workers to undercut native labour or to break strikes. As expressed by Odger, secretary of the London trades council, this internationalism was a blend of altruism (he spoke of "a will to co-operate for the good of mankind") ${ }^{7}$ and strong national interest, in that the lack of international solidarity was actively hampering national labour organization.

As Collins and Abramsky have shown, Marx's influence and theoretical guidance were incidental at this early stage of international labour cooperation. ${ }^{8}$ Yet the lasting legacy of the First International was precisely the marriage of two strands of the international movement: labour internation-

\footnotetext{
- See Georges Haupt, Michel Lowy and Claudie Weill, Les Marxistes et la Question Nationale, 1848-1914 (Paris, 1974); Eric Cahm and Vladimir Fišera (eds), Socialism and Nationalism in Contemporary Europe, 1848-1945, Volume I (Nottingham, 1978), pp. 7-19.

7 Address of the English to the French workers, signed by Odger and four other trade union leaders, and published in the Beehive, 5 December 1863. For an analysis of this address, see Henry Collins and Chimen Abramsky, Karl Marx and the British Labour Movement (The Years of the First International) (London, 1965), pp. 25-26, 39-40.

${ }^{8}$ See Collins and Abramsky, Karl Marx and the British Labour Movement, chapter III, pp. 31-38.
} 
alism, based on a desire for peace and freedom, but measured in concrete, practical terms, and socialist internationalism, based on the central assumption of the primacy of class as historical determinant. Undoubtedly, contact with workers abroad and, to a lesser extent, the influence of political thinkers such as Marx helped to radicalize the British labour movement, extending its vision from immediate, trade-based demands to wider questions of social and economic reorganization (notably, collectivization of the means of production). At the same time, workers abroad began to emulate British methods of labour organization and to recognize the results of the growth of the International in terms of numbers of trade associations created, the number of strikes, the successful outcome of strikes, sums collected to support strike movements, etc. In this very important sense, international organization was seen not as the expression of an automatic internationalism but as a means of building up national organization.

The end of the First International laid bare the tensions which existed between the cautious, corporatist internationalism of the English trade union leaders and the emancipatory, revolutionary mission of international organization as seen by socialists. At the same time, these tensions were exacerbated by a further factor determining international links: the struggle for power (and hence legitimacy) within the international movement by opposing ideologies, as shown by that between the Marxists and the Bakuninists in the last years of the First International. Later, the holding of two rival international congresses in Paris in 1889, both congresses marking the beginning of the Second International, gave material form to the conflict between "reformist" and "revolutionary" views of international activity, and also the struggle for legitimacy of rival socialist groups, the French division between "Marxists" and "possibilists" thus being projected onto the international level.

There is not room here to go into the Second International and its positions on international labour. What is clear is that, from an early stage, many of the labour organizations which had welcomed the international initiative played an uneasy role within the Second International. The French CGT represented an extreme example: after the 1896 London congress, when the International formally confirmed a clause stipulating the recognition of political action, the CGT refused to participate further in international socialist congresses. An autonomous labour confederation, the CGT decided after 1896 that it would participate only in purely labour congresses and organizations.

The CGT was not alone in its desire for the establishment of a labour International, especially after the Second International's formal acknowledgement of the necessity of political action in 1896. Many English trade unionists were alarmed by what they saw as a theoretical socialism divorced 
from the world of work. At the 1896 Trades Union Congress, several delegates as well as the conservative Parliamentary Committee expressed dissatisfaction with the results of the international congress which had taken place earlier that year. The prevalent opinion was that the mixture of socialists and trade unionists was not conducive to practical work, and although Ben Tillett secured agreement for his resolution calling for continued participation in international congresses, it was stressed that mandates from specifically working-class organizations should provide the basis for future international gatherings. ${ }^{9}$ When the General Federation of Trade Unions was set up in Britain in 1899, as a federal body which looked after the economic and industrial concerns of the labour movement (the TUC functioning as a policy-making "umbrella" organization), it looked not to the Second International but to contacts with labour federations of other countries.

Around the same time, international links within the labour movement were taking another direction, as leaders of trade associations of different countries met (often at international socialist congresses) and discussed questions of interest to their mutual trade. Initial contacts were reinforced during strikes or periods of emigration, when the benefits of close cooperation between members of the same trade in different countries became apparent. International trade secretariats (ITS) were formed from 1889 onwards, the first being the International Tobacco Workers' Federation. By 1900 , international secretariats had also been established by the hatters, glovers, shoemakers, miners, glass workers, metalworkers, textile workers, printers, transport workers, and workers of other, smaller trades. ${ }^{10}$ The initiative for such associations usually came from the countries where organization of the trade was the strongest, principally from England and Germany, but also (depending on the location of the centres of production) from France, Belgium, Switzerland, The Netherlands. it was, for example Belgian and Dutch cigar-makers who, with the co-operation of their German counterparts, set up the first ITS (the International Tobacco Workers' Federation) in 1889.

The trade-specific nature of the links ensured their coherence and stability, and they still exist today in one form or another. Such questions as the transfer of union membership from one country to another when workers emigrated were naturally easier to settle and implement within the same trade rather than in discussions involving workers of all trades, and problems which were specific to one trade or industry (safety conditions in

\footnotetext{
${ }^{9}$ Report of the Proceedings of the Twenty-Ninth Annual Trades Union Congress, Edinburgh, 1896, pp. 23 (Report of Parliamentary Committee), pp. 32-34.

${ }^{10}$ See Walther Schevenels, Forty-Five Years IFTU (Brussels, 1945), pp. 20-21.
} 
mines, or the use of noxious substances in certain industries, for instance) were likely to receive closer attention from representatives of the workers concerned than in more general gatherings.

The Second International activily encouraged workers to join their respective ITS. Indeed, many of the ITS retained close ties with the Second International and most timed their congresses to coincide with those of the Socialist International, whilst retaining limited, trade-specific goals. Later, some international trade federations would take up questions of wider political and economic significance, ${ }^{11}$ but initially the contacts were very tentative, and the tasks of the secretariats were usually confined to the distribution and exchange of information on the situation of the trade in different countries. In this, the ITS played an important role in the international organization of labour, by pointing to the concrete benefits of restricting international activity to immediate working-class demands.

In one important sense, however, trade federations were ill-equipped to deal with a question which was increasingly preoccupying national labour organizations: the need for protective legislation, which had to be tackled on an national level. English trade-union leaders were already convinced that the way forward for the labour movement lay in the combination of strong trade unions and a presence in Parliament (through lobbying at first, and even alliances with middle-class reformers, but later through the formation of an independent labour party whose task was to translate workers' aspirations into legislative proposals). The German labour leaders shared this view of the respective roles of union and party, and the implications of this tendency within the German labour movement were to be far-reaching, both for the German labour movement and indeed for the whole of the international movement.

German labour organization, under anti-socialist legislation, had developed as a non-political movement, with emphasis instead on "bread-andbutter" issues and the building-up of financial and numerical strength. Even when this legislation was lifted, the German labour movement, under the leadership of the General Commission of the Free Trade Unions, retained its non-political stance. This refusal to tackle political issues naturally precluded any revolutionary activity; for the German labour leaders, trade unions had necessarily to work within the existing social framework. As the leader of the General Commission, Legien, explained to SPD congress delegates in 1899, organized workers did not want social upheaval (Kladderadatsch); instead they wanted "peaceful development". ${ }^{12}$ The job

1 The congresses and activities of the International Transport Workers' Federation and the International Miners' Federation, in particular, grew more ambitious in the years leading up to the First World War.

${ }^{12}$ Legien's speech is quoted more fully in Heinz Josef Varain, Freie Gewerkschaften, Sozialde- 
of trade unions was to reform existing social conditions, argued Legien, and it was left to the SPD to elaborate projects for future society. Thus the "two arms" strategy of German social democracy was developed, the trade unions organizing workers around economic demands, and the socialist party expressing the aspirations of the working class on the political level.

Important qualifications must be made here, however. By 1900, the German trade union movement had developed to such an extent that it formed a separate power base within German social-democracy. With one million members of the Freie Gewerkschaften by 1904 (a number which was climbing constantly), the ratio between SPD members and trade unionists was changing in favour of the latter. This was crucial, since labour leaders such as Legien (who was also a socialist deputy) saw the trade union movement as the main focus of activity, in contrast with other members of the SPD who viewed the unions as a mere recruiting-ground for the party. As John A. Moses has remarked, Legien's steady and determined work "liberated the unions from the party", a development which was to show that "it was the party which had to fear the tutelage of the General Commission". ${ }^{13}$

The radical wing of the party had reason to fear the consequences of the unions' relative strength, since Legien and other labour leaders saw the SPD not as an agent of revolutionary change but as a political outlet for trade union demands. Trade union demands for "neutrality" did not represent a push for separation from the party, but a claim to recognition on at least equal footing with the party, plus freedom of action for the unions on one hand, and the right to veto any party policy affecting workers on the other. (This was later achieved in the "Mannheim agreement" of 1908.) Inevitably, the trade union position strengthened reformism within the party.

Legien's refusal to tackle political questions was rigidly adhered to in the German labour movement, and any questions which were seen as political in nature were banned from congresses and publications of the Free Trade Unions. Paradoxically, however, this went hand in hand with another aspect of the trade unions' "neutrality" drive: the right to tackle social reform questions (Sozialpolitik), which were in fact the domain of the SPD. By carrying out its own enquiries into legislation and working conditions and by forging links with government bodies, the German trade union

mokratie und Staat. Die Politik der Generalkommission unter der Führung Carl Legiens (1890-1920) (Düsseldorf, 1956), p. 20.

${ }^{13}$ John A. Moses, Trade Unionism in Germany (1869-1933), Volume I (London, 1982), p. 138. Moses has written extensively on Legien's role in shaping the German labour movement and on his conception of trade union activity. On Legien's influence on the German labour movement, see also the "official" biography by Theodor Leipart, Carl Legien: Ein Gedenkbuch (Berlin, 1929). 
movement was trying to push the SPD in the desired direction: towards the representation of the labour cause in the Reichstag. ${ }^{14}$

An understanding of the preoccupations of the German labour movement is necessary in order to explain the development of the International Secretariat of National Trade Union Centres (created in 1901) and indeed that of the Second International. From the beginning, Legien saw the international arena as a means of imposing his own views on the socialdemocratic movement nationally and internationally. In 1893, for example, Legien quoted the recommendations of the Zurich congress of the Second International, which emphasized the need for strong national labour federations, as a means of boosting the standing of trade unions at home. ${ }^{15}$ Around the same time, Legien began to approach labour leaders of other countries with a view to setting up an exclusively labour organization on the international level. In 1896, for instance, Legien ended his report to the International Socialist Congress of London with an appeal aimed specifically at the TUC for closer links between trade union federations. ${ }^{16}$ The refusal of the English trade unions to respond to this appeal left Legien feeling rather bitter about the English trade union movement, ${ }^{17}$ but his request did have the effect of bringing the German, Austrian and Danish federations into closer contact. ${ }^{18}$

Since the Second International had already made it clear that it intended to speak on behalf of international labour by its resolutions on international legislation of labour, Legien's attempts to give international activity a more overtly trade-union profile may be seen as part of the General Commission's drive for "neutrality". At the very least Legien's initiative showed

${ }^{14}$ On Legien and Sozialpolitik, see John A. Moses, "The Trade Union Issue in German Social Democracy 1890-1900", Internationale Wissenschaftliche Korrespondenz zur Geschichte der Arbeiterbewegung, 19/20, 1973, pp. 1-9. On the "neutrality" debate, see Gerhard Ritter, Die Arbeiterbewegung im Wilhelminischen Reich. Die sozialdemokratische Partei und die Freien Gewerkschaften 1890-1900 (Berlin, 1963), and Wolfgang Schröder, "Partei und Gewerkschaften. Marxistische und trade-unionistische Konzeption der Gewerkschaftsdebatte nach dem Kölner Parteitag", Beiträge zur Geschichte der Arbeiterbewegung, 1973, pp. 630-649.

${ }^{15}$ See Correspondenzblatt, 1893, 18, pp. 69-71.

${ }^{16}$ Congrès International des Travaillelurs et des Chambres Syndicales Ouvrières tenu à Londres du 26 juillet au 2 août 1896 (Geneva, 1980 reprint), p. 654.

${ }^{17}$ See Correspondenzblatt, 1902, p. 102. Why the English should be so reluctant to take up an initiative which came from a workers' representative, rather than from a socialist, is unclear, since trade unions continued to participate in the congresses of the Second International. Debate at the 1896 TUC had indicated that labour congresses would be more useful than socialist congresses. On the other hand, continued participation in the Second International required no guidance from the TUC leadership; it was left to individual unions to take part, whereas Legien's project was obviously aimed at the national labour federations and would therefore have demanded top-level commitment. The Parliamentary Committee was presumably reluctant to act in this direction.

${ }^{18}$ So Legien reported to the English GFTU in 1901. GFTU, Second Annual Report, 1901, p. 44. 
that he considered international socialist congresses to be too wide in scope to tackle practical questions efficiently. Legien's views on the relative merits of full congresses and more restricted conferences were stressed repeatedly during international trade union conferences after 1901. The German labour leader was not alone in seeing the need for a separate trade union initiative, and links between Legien and the Austrian and Danish labour leaders, following the London international congress of 1896 , led to the first conference of the International Secretariat of National Trade Union Centres (ISNTUC) in 1901.

Besides the German General Commission, the other major influence in the initiative to set up formal links between labour federations was the Scandinavian movement. Walther Schevenels of the IFTU later acknowledged the important lead which the Scandinavian movement had given. ${ }^{19}$ From 1886 , trade union leaders of Denmark, Sweden and Norway held regular joint conferences, developing a unified outlook and policy and reaching agreements, such as those on mutual strike assistance and exchange training programmes for young workers. The Danish labour movement, which had been the first to organize among the Scandinavian countries, took the lead. In Denmark, the labour and socialist movements had developed together since 1880 , and unity of action had strengthened the labour movement. Its membership figures, financial security and influence in political life compared favourably with those of the labour movements of Germany and England. ${ }^{20}$ Moreover, the Danish labour movement had strong internationalist traditions, since it had originally been organized as a section of the First International. ${ }^{21}$

It was in Copenhagen, on the occasion of the Scandinavian labour congress in August 1901, that the foundations of the ISNTUC were laid. As well as the three Scandinavian countries, Germany, Finland, Belgium and England were represented. Like the Scandinavians, the Belgian movement was characterized by unity of action between labour and socialism in the Parti Ouvrier Belge. As for England, it was represented by the GFTU, which since its formation had been inspired by the German and Danish

${ }^{19}$ See Schevenels, Forty-five years IFTU, p. 19.

${ }^{20}$ Isaac Mitchell's admiration of the Danish labour movement is evident in his account of the Scandinavian labour congress in Copenhagen, 1901: GFTU, Ninth Quarterly Report, September 1901, p. 9. On the influence of the Scandinavian labour movement, and especially the Danish, De samvirkende Fagforbund (DsF), see Søren Federspiel, "Fagforeningsinternationalen og DsF til 1914", Aarbog for arbejderbevœgelsens historie, 1978, pp. 6-54.

${ }^{21}$ See report of the Danish labour federation to the London congress of the Second International: Congrès International Socialiste des Travailleurs et des Chambres Syndicales. Ouvrieres, London, 1896 (Geneva, 1980 reprint), p. 705. 
federations, whose statutes and reports were regularly published in GFTU documents.

Given such a select gathering, agreement was easy to achieve. In a meeting lasting only a few hours, which took place after the Scandinavian labour congress, the trade union leaders laid down what were to be the bases of the ISNTUC. From the outset, Legien took an undisputed lead. Unlike the other labour leaders, Legien had prepared in advance a series of proposals which he laid before the meeting. He argued that full-blown international congresses were impractical, because not all national centres were sufficiently or uniformly organized. Any decisions reached on general questions would be impossible to implement under such conditions, he argued, but questions of immediate and practical interest, concerning national labour federations, could be thrashed out in brief meetings of the national secretaries, to take place during national labour congresses. All those present accepted the proposal and further agreed that in future all appeals for strike aid should be sent via the national federation of the country concerned to the national federations of other countries. ${ }^{22}$

Although brief and deliberately unambitious in scope, the Copenhagen meeting laid down the essential organizational principles which were to guide the work of the ISNTUC. The need for strong national centres was stressed, and the authority of these national federations reinforced by the resolution controlling appeals for strike aid. National secretaries were acknowledged as the sole representatives of the labour movement of each country. Finally, the self-imposed limitation of discussions between trade union leaders to purely practical matters (strike aid, membership transfer agreements, exchange of information) reflected the German concern for trade unions to tackle questions of immediate concern to workers, including limited social legislation, but to exclude wider political and social questions from the agenda. Implicit in this limitation of the ISNTUC was a recognition that the Second International represented the correct forum for wider, theoretical debates.

The second international meeting was held under the auspices of the German labour congress in Stuttgart, June 1902. Here, membership was widened to include representatives from France, Italy, The Netherlands, Austria, Switzerland and Spain. Again, the meeting was very brief (Legien referred to four hours' work). It was decided that a central committee should co-ordinate activities between conferences, the national centre of Germany (as host of the Stuttgart conference) to act as central secretariat until the next conference. The meeting then formally adopted a principle

22 Première Conférence Internationale des Secrétaires Nationaux des Syndicats, Copenhagen. 21 August 1901 (Hamburg, no date). 
which had been indirectly mooted at Copenhagen, declaring that only one national centre could be admitted per country. ${ }^{23}$ Conferences were to take place every two years, to be organized in conjunction with the holding of national labour congresses, and were to discuss only questions which had been submitted to the International Secretary and approved in advance.

It was at the third international conference, held in Dublin in July 1903, that the ISNTUC adopted a more formal structure. Legien proposed that, instead of the duties of the central committee being rotated, a permanent secretariat should be elected, and that membership fees be introduced to cover the costs incurred. ${ }^{24}$ Accordingly, Legien was elected International Secretary, and, although the feeling was expressed at Dublin that the post should be rotated at a later date, it was a post which Legien was to occupy until 1919. ${ }^{25}$ The International Secretary's main task was to collect from each country yearly reports on the progress of the labour movement and to publish these reports, together with an international overview and the accounts of the ISNTUC, in English, French and German. The first such report appeared in $1904 .{ }^{26}$ In cases of major strikes and industrial conflicts, the secretariat was to collect and distribute weekly reports. In addition, the International Secretary was responsible for making available translations of legislative bills and other material likely to be of interest to national labour leaders, for drawing up uniform statistics, and for arranging the provision of strike aid.

John Price, in his study of the international labour movement, has remarked that the tasks of the International Secretariat were similar to those of the Central Council of the First International almost forty years earlier. ${ }^{27}$ Certainly these early conferences laid the groundwork for the later development of the IFTU. ${ }^{28}$ It should also be noted that the ISNTUC's international reports provided a rich source of information on the interna-

\footnotetext{
${ }^{23}$ Protokoll der Zweiten Internationalen Konferenz der Sekretäre der Landesorganisationen der Gewerkschaften, Stuttgart, 1902 (Stuttgart, no date), p. 18.

${ }^{24}$ Report of the Third International Conference of Trade Union Federations, Dublin, 1903 (Hamburg, no date), p. 5. Fees were initially fixed at $6 \mathrm{~d}$. per 1000 members of the national federation.

${ }_{25}$ In 1913, the post was upgraded to that of International President, but it was still occupied by Legien, who, despite attempts during the war to transfer the headquarters of the organization to a neutral country, maintained his position until the end of the war. At the Amsterdam congress in 1919, when the IFTU was reconstituted. Legien was elected as one of the Vice-Presidents, but declined to take up this post because he had wanted to keep the presidency.

${ }^{26}$ First International Report of the Trade Union Movement, 1903 (Berlin, 1904).

${ }^{27}$ John Price, The International Labour Movement (Oxford, 1945), p. 32.

${ }^{28}$ Hans Gottfurcht, a former General Secretary of the International Confederation of Free Trade Unions, acknowledged the importance of the early ISNTUC decisions for the IFTU and the ICFTU in his book, Die internationale Gewerkschaftsbewegung im Weltgeschehen (Cologne, 1962), p. 32.
} 
tional labour movement overall, although the nature and depth of information on member countries varied. That the reports appeared at all was largely due to Legien, who produced the international report and strove constantly to impose uniform guidelines for the compilation of individual national reports. In this respect, the work of the International Secretariat was in advance of that of the Second International. ${ }^{29}$ Unfortunately, national reports from ISNTUC members were often late or, in Legien's eyes, inadequate, which served to confirm Legien's view that unequal degrees of organization in individual countries necessarily limited international co-operation. ${ }^{30}$

The ISNTUC was further strengthened by closer ties with the international trade secretariats. In 1901, discussion which took place at the Scandinavian labour congress made it clear that national organization was paramount: trade or industrial federations should first affiliate to their national federation, and only then to their respective international trade secretariat ${ }^{31}$ Accordingly, it was not until the ISNTUC had consolidated its own position that it looked to the ITS. At the fifth international conference in Christiania (Oslo) in 1907, this principle was reiterated. Once trade federations were affiliated both to their national federation (which in turn would be represented in the ISNTUC) and then to their ITS, this would "further international brotherhood of workers by maintaining intimate relations in all directions". ${ }^{32}$ Even so, fears were expressed in some quarters that the emphasis placed upon international union might retard national organization. This tension between international links between trade-specific organizations and the authority of national federations was not eased until 1913, when representatives of twenty-three ITS attended the international conference in Zurich. Around the same time, some ITS began to use the International Secretariat as an information and translation centre. This marked a shift for the ITS away from the Second International (many of the international trade congresses being held at the same time and place as the international socialist congresses, to avoid duplicating travel costs) and

29 The International Socialist Bureau was set up after the Paris congress in 1900, but it was unable to produce reports as planned for the Amsterdam congress in 1904. It was not until the Stuttgart congress in 1907 that the ISB was able to report some progress in publishing reports, collecting material for a library and conducting a survey on the relationship between parties and trade unions. See Rapports et projets de résolution présentés de Stuttgart (Geneva, 1978), pp. LXI-LXX (English introduction by Camille Huysmans).

${ }^{30}$ See, for example, discussion at the 1911 conference: Seventh International Conference of the Secretaries of National Trade Union Centres, Budapest, 1911, in Eighth International Report of the Trade Union Movement, 1910 (Berlin, 1911), pp. 23-24.

${ }^{31}$ See GFTU, Ninth Quarterly Report, September 1901, p. 8.

${ }^{32}$ Report of the Fifth International Conference of the Secretaries of the National Trade Union Centres, Christiania, 1907, in Fourth International Report of the Trade Union Movement, 1906 (Berlin, 1908), p. 21. 
therefore a shift in the centre of gravity of the international labour and socialist movements, consolidating the ISNTUC's authority as the representative body of international labour.

The representativeness of the ISNTUC as an international body was further strengthened in 1911 by the affiliation of the American Federation of Labor (AFL), swelling ISNTUC membership figures by almost two million. This new affiliation had the effect of modifying the ISNTUC's organizational base, since it was in deference to American methods of organization that the name of the ISNTUC was changed in 1913 to that of International Federation of Trade Unions, and the new post of President created. This move was little more than a cosmetic change, reflecting the increased confidence and authority of the international body. In practice, the change of title did not bring with it a corresponding transformation of the organization's structure or methods of working. The International Federation of Trade Unions remained, until its reconstitution after the war, basically a central correspondence committee, to exchange information and provide administrative services. Nor, as we shall see, did the change of title signify a widening of the scope of international conferences.

The Amsterdam conference of 1905 defined the object of international conferences as being to "consider the closer union of the trade unions of all countries, uniform trade union statistics, mutual help in economic struggles, and all questions in direct connection with the trade union organization of the workers" ${ }^{33}$ Decisions reached by the international conferences fall into four main areas: international strike aid, immigration of foreign workers and the related question of importation of "blacklegs", reduction in working hours, and social protection measures (night work and home work).

In terms of practical achievements, strike aid was the ISNTUC's greatest success. Almost all the conferences occupied themselves with the organization of strike aid, formulating an elaborate system of rules which stressed both national obligations (the ISNTUC was to become involved only when national resources had been exhausted, and only directly through the national centre concerned) and the autonomy of each national centre to respond to the appeal as it saw fit. ${ }^{34}$ Despite the restrictions, designed to reinforce the authority of national centres on the national level and that of the ISNTUC on the international level, considerable sums were raised, and international solidarity was boosted. In 1913, for instance, the sum of

${ }^{33}$ Bericht über die Vierte Internationale Konferenz der Sekretäre der gewerkschaflichen Landeszentralen, Amsterdam, 1905, in Zweiter Internationaler Bericht über die Gewerkschaftsbewegung, 1904 (Berlin, 1906), p. 30.

${ }^{34}$ See USNTUC, "Decisions of International Conferences", Eighth International Report, pp. 46-47. 
$£ 2470$ was passed on to Dutch tobacco workers out on strike, and the International Secretariat collected $£ 520$ for the Belgian general strike in the same year. ${ }^{35}$ Another notable example was the Swedish general strike of 1909. The International Secretary's appeal for financial assistance resulted in centres sending funds directly to the Swedish federation, which thanked the ISNTUC members at the Paris (1909) and Budapest (1911) conferences. In these and other cases, international co-operation demonstrated its practical use. As with the compilation of reports, however, the response among ISNTUC members to such appeals was unequal, and often international conferences were used to single out federations which were seen as lacking in international solidarity (usually the English and the French). ${ }^{36}$

On the question of transfer of union membership from one country to another when workers emigrated, the international conferences were also able to reach important agreements. These agreements complemented those already concluded within international trade secretariats. ${ }^{37}$ The emphasis was once again on the importance of organization, the presence of unorganized (particularly foreign) workers being seen as a major obstacle to the improvement of pay and working conditions. On the other hand, the question of the use of foreign workers as strike-breakers was more problematic: firstly, because although it was relatively easy to pass resolutions condemning such practices, ${ }^{38}$ discussion of measures to stop them was an extremely delicate area (such measures were discussed at international conferences, but in complete confidentiality, and therefore no record of these discussions exists); secondly, because representatives of countries known as suppliers of "blacklegs" stood accused at international conferences by those whose members suffered directly as a result of the use of foreign labour during industrial disputes. The English delegate, Curran, for instance, was placed very much on the defensive at the Christiania conference on this question. ${ }^{39}$ Ultimately, as Curran himself was forced to

\footnotetext{
${ }^{35}$ Schevenels, Forty-five years IFTU, p. 51. It is difficult to assess just how much was collected through the International Secretariat, since most centres responded to appeals by sending money directly to the national centre involved, especially before 1913. Certainly the examples given concern only money sent via the International Secretary, and the total sums must have been higher.

${ }^{36}$ See, for example, report of Budapest conference, in Eighth International Report, p. 27, and Report of the Eighth International Conference of the Secretaries of National Trade Union Centres (Berlin, 1913), pp. 22-23.

${ }^{37}$ See report of Christiania conference, Fourth International Report, pp. 20-21.

${ }_{38}$ As the ISNTUC did at Christiania and Paris. See Report of Christiania, Eighth International Report, p. 25; Report of the Proceedings of the Sixth International Conference of the National Trade Union Centres, Paris, 1909, Sixth International Report of the Trade Union Movement (Berlin, 1910), pp. 37-38.

${ }^{39}$ Christiania, Report, p. 25.
} 
admit, those who were involved in breaking strikes usually stood outside the reach of the organized trade union movement.

Similarly, on questions of working conditions - the eight-hour day, abolition of night work and control of home work - the national labour representatives were usually confined to expressing their members' wishes on these matters, and recommending that social-democratic parties should place bills before Parliament to enforce those demands. The ISNTUC did have an important job to carry out in this area, however: the collection of information on conditions in different countries and on legislation already in force, which would help to back up the labour federations' arguments at home. Here, the ISNTUC's work clearly mirrored Legien's own preoccupations at home.

Even with these limited objectives, however, the ISNTUC members showed themselves to be reluctant to commit their federations to concrete action. Indeed, Legien himself was forced to admit, at the Dublin conference in 1903, that a model report, which he had earlier offered to produce as a guide for other members, had not been written because the German labour leaders had been too busy preparing for the Reichstag elections. ${ }^{40}$

Attempts to gather together information on questions of central importance to workers' organization were constantly put off or even dropped. At the fourth international conference in Amsterdam, for instance, most delegates agreed with a Danish proposal that the ISNTUC should set up an international survey into working hours in the different countries - purely a fact-finding job. But Legien, from his experience in putting together international reports, knew only too well the difficulty which members found in compiling documentation and meeting deadlines (he constantly bemoaned the lackadaisical way in which national reports were produced), and he therefore warned that, unless all members were prepared to commit themselves wholeheartedly to the task, there would be no use in passing such a resolution. ${ }^{41}$ Two years later, Legien reported that few reports had been received, and even those were, in his opinion, inadequate. He therefore proposed that the survey be abandoned. The Danish representative, Olsen, tried to salvage something from the project, securing agreement for his resolution, which urged each national centre to produce information on working hours as soon as possible..$^{42}$ But by 1913 , this had still not been done..$^{43}$

In this way, the work which the ISNTUC fixed for itself, and therefore also the goals which it set, were strictly limited. On one hand, this was due

${ }^{40}$ Dublin, Report, p. 8.

${ }^{41}$ Amsterdam, Zweiter Internationaler Bericht, p. 29.

${ }^{42}$ Christiania, Report, pp. 22-23.

${ }^{43}$ Report of the Eighth International Conference, Zurich, 16-18 September 1913 (Berlin, 1913), p. 37. 
to the fact that not all national centres were equally committed in terms of enthusiasm and resources to the organization and indeed to international activity. On the other hand, this argument was used by Legien voluntarily to limit expectations and therefore the work undertaken. It could be argued that a more vigorous leadership of the ISNTUC (as opposed to the deliberately restraining influence which Legien exercized), coupled with a more ambitious approach to questions of international importance, might have had the effect of pulling along the more reluctant members of the organization to bring them into line. That, at least, was the view of some of the more revolutionary elements within the international movement.

The clash between Legien's reformist interpretation of labour activity, which increasingly came to dominate the ISNTUC, and the syndicalist attitudes prevalent in the French CGT overshadowed much of the ISNTUC's work and discussions. ${ }^{44}$ The widening of the ISNTUC's membership in 1902 to include most of the major labour movements of Europe meant that the limitation of the international organization to purely practical questions (and the acknowledgement of the Second International's competence to speak on more general matters, which this implied), agreed at Copenhagen, were contested by those labour movements which stood outside the social-democratic movement: the French CGT and the Dutch Nationaal Arbeids Secretariaat (NAS). At Stuttgart, the French and Dutch representatives advocated the holding of international labour congresses, at which each national labour movement would be represented by delegates mandated to discuss and decide on a wide range of issues. Whereas the conferences initiated by Legien aimed to exclude all questions of tactics and tendencies, the French and Dutch wished to encourage debates between labour representatives of all shades of opinion. Moreover, international congresses, because of their representative nature and their extended competence, would present a direct challenge to the Second International. Van Erkel's resolution (for the NAS) in this sense to the Stuttgart conference received short shrift from Legien, who declared that "the general opinion was in favour of International Conferences". ${ }^{45}$

In 1903, the French changed tack and attempted to force the international conference to broach the subjects of antimilitarism and the general strike, by including them in a verbal report which the CGT hoped to read at Dublin. The conference was over before the French delegates had the

44 These conflicts are more fully explored in Susan Milner, "The French Confédération Générale du Travail and the International Secretariat of national Trade Union Centres, 1900-1914: French syndicalist attitudes towards internationalism and the international labour movement" (Ph.D., Aston University, 1987). [Hereafter "The French Confédération Générale du Travail"].

${ }^{45}$ Stuttgart, Protokoll, p. 7. 
chance to read out their carefully-prepared report. ${ }^{46}$ The CGT leaders therefore decided that they should have the questions, together with that of the eight-hour day, formally placed on the agenda of the next conference, but this met with stern disapproval from the International Secretary, and the ensuing bitter quarrel between the CGT leaders and Legien meant that the French stayed away from the next two conferences in 1905 and 1907.

In the absence of the French, Legien moved quickly to isolate them in the international movement. A formal resolution was passed, which stated explicitly that the task of international conferences was to discuss only questions directly affecting workers' organizations and that "all theoretical questions and those dealing with the tendencies and tactics of the Trade Union movements in the different countries, are excluded from the debates". ${ }^{47}$ It was made clear that international socialist congresses were regarded as the proper place for discussion of questions such as antimilitarism and the general strike, which were not the concern of trade unions.

Moreover, the Christiania conference went beyond this statement of views and actively censured the French confederation, criticizing it as unrepresentative and unrealistic, and directing the French labour leaders to consider such issues as the general strike and antimilitarism "in conjunction with the political organization of the working class of their own country and to contribute towards the solution of those questions by participating in the international socialist congresses" ${ }^{48}$ In this case, the ISNTUC had exceeded its own mandate by interfering in the tactics of a member federation.

The Dutch NAS, which stayed away from the 1907 conference in protest at the way the CGT had been treated, was immediately replaced by its rival, the Dutch social-democratic labour federation. The isolation of the French labour federation in the international movement was thus complete. Forced by the logic of its own internationalist and antimilitarist policy and by pressure within its own ranks from dissident groups which were ideologically closer to the tendencies represented in the ISNTUC (both socialist and reformist), to seek international ties, and faced with the lack of a viable

\footnotetext{
${ }^{46}$ This particular incident was later used by the CGT leaders to demonstrate the sterility of international conferences. At the 1909 congress of the CGT, for example, Robert, who had been involved in drawing up the CGT's report on antimilitarism and the general strike in 1903, spoke scornfully of the Dublin conference: "What did our friends do at Dublin? [. . .] Griffuelhes and Yvetot have told you that they were led into spending an enormous amount of the proletariat's money, and to do what? to watch a car race. And after the conference, you receive a publication which no-one reads [ . . ], a pamphlet full of statistical information which is only of relative interest to you", XVIe Congrès international corporatif(Xe de la CGT), Marseille, 5-12 octobre 1908, p. 61. See also Griffuelhes' bitter personal account of the Dublin conference in his book, L'Action Syndicaliste (Paris, 1908), p. 55.

4 - 1 msterdam, Bericht, p. 30.

4s Christiania, Report, p. 16.
} 
alternative, ${ }^{49}$ the CGT resumed participation in international conferences in 1909 and continued to press for the widening of the scope of international conferences. The CGT had no success in this endeavour, however. At the Zurich conference in 1913, when it was decided on the AFL's proposal that the ISNTUC become a "federation", the AFL delegate made it clear that "this concerns only the change of the present name and not of the organization", ${ }^{0}$ and the CGT's proposal for the holding of international congresses was once again decisively rejected. As a result, relations between the French centre and the other members of the ISNTUC, particularly the Germans, grew increasingly embittered.

The consequences for the CGT of this continued battle within the ISNTUC were serious indeed, although we do not have room to consider them here. ${ }^{51}$ We must however look here at the impact of this conflict on the ISNTUC. Plainly, it hindered the development of closer ties within the international movement. Discussion at international conferences was often dominated either by arguments between the French and other centres, or by attempts to consolidate the majority position in the face of French attack (as at Amsterdam and Christiania). A considerable amount of time was thus spent over negative, rather than positive, definitions of international activity. Secondly, in its determination to concede nothing to the revolutionary-syndicalist position, the ISNTUC became entrenched in its very limited concept of labour activity, since any attempt to boost international activity was seen as a challenge to the authority of the ISNTUC leadership. Furthermore, the isolation of the syndicalist position served to unite artificially those who were in opposition to it, and hence other divisions within the ISNTUC were diminished. In this way, more radical organizations such as the Austrian and the Danish federations went along with the reformist leadership, instead of attempting to identify the ISNTUC more strongly with socialism.

Finally, it must be said that, as relations between the French and other national centres deteriorated, the ISNTUC failied to promote internationalism actively. Indeed, as the Franco-German conflict demonstrated, international consensus was impossible to achieve where national differences arose, because it would have compromised the fundamental principle of the primacy of national organization.

From the first meeting of the ISNTUC in 1901, it was made clear that international links had to be predicated on the principle of strong national

49 See Milner, "The French Confédération Générale du Travail", chapters V and VI. On the revolutionary syndicalist challenge to the ISNTUC, See Wayne Westergard-Thorpe, "Revolutionary Syndicalist Internationalism 1913-1939. The origins of the International Working Men's Association" (Ph.D., University of British Columbia, 1979).

so Zurich, Report, p. 34.

${ }^{51}$ See Milner, "The French Confédération Générale du Travail". 
organization. International meetings were to take place under the auspices of national labour congresses, and strike aid to be channeled through national federations. At the second international conference in 1902, the question of national organization was raised when delegates decided that national centres should in turn act as central committee. This decision, together with the emphasis placed on the responsibilities of individual centres in the matter of strike aid, caused some delegates to insist on the formal recognition of only one centre per country.

The English, Swiss and Austrian delegates were particularly keen on such a requirement, reflecting an awareness of the need to assert their own authority, in the face of opposition at home. Between the English GFTU and the TUC there was a deep-seated rivalry, since each hoped to recruit from the same unions. In Switzerland, several anarchist-influenced unions remained outside the social-democratic movement, although, as Calame of Zurich hastened to point out at Stuttgart, these unions represented no real threat to the latter. ${ }^{52}$ It was perhaps the Austrian centre, however, which had the most to gain from recognition as the sole legitimate national representative. Because of the multiplicity of nationalities incorporated in the Austrian empire, the centralization of the Austrian labour movement, under a German-speaking leadership, was contested by organized workers of the linguistic minorities, especially in Bohemia, where Czechs represented the majority. To dispute the capacity of the Austrian Commission to represent all workers of the Austrian empire would have been to question the principle of centralized leadership, and consequently the Stuttgart conference agreed with Hueber, the Austrian labour leader, that his organization alone was a representative national centre.

Along with the principle of strong national organization, the 1902 conference therefore also emphasized that of centralized leadership. The 1902 decision laid down the basis for further discussion: there was to be only one national centre for each country, and the primary duty of trade unionists was to strengthen that organization. Since, in most countries, the national labour leadership was challenged by rival groups (within or outside the mainstream labour movement), this decision inevitably provoked conflict.

The question of rival federations, raised by representatives of the "narrow" Bulgarian unions (the "broad" unions having already affiliated to the ISNTUC) and by the American Industrial Workers of the World (IWW), proved to be the main sticking-point at the 1911 conference in Budapest. The situation of the Bulgarian unions mirrored the political split between the leftist "narrow" and the reformist "broad" parties, and resulted in a heated exchange between representatives of the two groups at Budapest. Most of the ISNTUC members were baffled by the background to the split,

${ }^{52}$ Stuttgart, Protokoll, p. 5. 
and could not decide between the two centres. On the suggestion of those centres most directly involved with the Bulgarian unions (Austria, Hungary, Croatia, Bosnia and Herzegovina), it was recommended that "the two national centres should try anew to come to an understanding (amalgamation)" and that, until then, both centres should remain outside the International Secretariat. ${ }^{53}$ Although, by issuing such a directive, the ISNTUC was effectively interfering in the tactics of an individual centre, its decision was evidently motivated by a desire not to become involved in the bitter strife between the two groups. Interestingly, the International Socialist Bureau was also drawn into the Bulgarian conflict in its attempts to encourage unity between the Balkan socialist parties. In the context of its antiwar activities, the ISB intervened directly in October 1911 to urge both parties to participate together in a Balkan socialist conference. ${ }^{54}$ The ISNTUC's appeal for unity may therefore be seen as part of wider international initiatives for peace. ${ }^{55}$

As far as the USA and Austria were concerned, however, the ISNTUC offered different solutions. Samuel Gompers, president of the AFL, attended an ISNTUC conference for the first time in 1909, explaining that he would recommend affiliation at the next AFL congress. By 1911, the AFL had indeed affiliated to the ISNTUC, but, around the same time, its rival, the IWW, also applied for membership. On this occasion, the issue was seen as a straight choice between the AFL and the IWW, since both could not represent the same country. At the Budapest conference, the members of the International Secretariat quickly took up position on the AFL/IWW conflict, according to their own preoccupations and tendencies. The IWW standpoint, which was put across as "purely revolutionary", ${ }^{56}$ was supported by the CGT. The AFL, on the other hand, received the backing of the remainder of the delegates, despite some question marks over alleged alliances between the AFL, business concerns and government agencies, and it was duly accepted as the American national centre. ${ }^{57}$ Since it was the IWW, and not the non-socialist AFL, which was represented at congresses of the Second International, this decision marked the distance between the ISNTUC and international socialism. It was left to the French CGT leader, Jouhaux, to reflect ironically on the difference between the ISNTUC's

\footnotetext{
${ }^{53}$ Budapest, Report, Eighth International Report, p. 25.

${ }^{54}$ See Georges Haupt, Socialism and the Great War: the Collapse of the Second International (London, 1972), pp. 66-72, on the ISB and the Balkan socialists.

ss The International Secretariat collected $£ 4000$ for the reconstruction of unions in Serbia and Bulgaria, but was unable to report any progress at the Zurich congress of 1913 . Zurich, Report, pp. 20.21 .

${ }_{56}$ The words are those of Foster of the IWW. Budapest, Report, Eighth International Report, p. 22.

${ }^{57}$ See debates in Budapest, Report, pp. 21-23.
} 
treatment of the Bulgarian split and of the American situation. ${ }^{58}$

The roots of the Czech/Austrian problem went much deeper, and the problem called for an understanding of the complex relationship between nationalism and internationalism. The Czech labour leaders attempted to gain recognition from the ISNTUC for their own movement, when they attended the 1905 conference in Amsterdam. Here, Nemec pleaded for separate affiliation for Bohemia on the grounds of the right of national groups to autonomous organization. The political or economic orientations of the Austrian leadership were not questioned; it was simply a matter of whether the Austrian labour leadership could adequately represent workers of different national, cultural and linguistic origins. On behalf of the Austrian unions, Hueber emphatically rejected Nemec's claims, accusing him of nationalistic attitudes. The rest of the ISNTUC members were equally categorical in their refusal of Czech demands, since they saw the issue as one of national organization. To concede to the "separatist" demands would, in their view, have constituted a setback to the formation of centralized national movements. The ISNTUC members therefore allowed Nemec to stay as an observer, but proposed that in future Czech labour representatives should work in close co-operation with the Austrian leadership. ${ }^{59}$ As a result, Austrian delegations at subsequent ISNTUC meetings usually included one German-speaking and one Czech representative. In reality, however, the ISNTUC's proposal solved nothing, because the Czechs continued to press for separate recognition, turning their attention to International Socialist Congresses. At the 1910 congress of the Second International, the conflict resurfaced. Here, the debate echoed the ISNTUC's discussions, opposing even more clearly two distinct views of labour organization: centralization versus autonomy. ${ }^{60}$ As Georges Haupt has remarked, the deeper significance of this debate escaped the delegates at the Copenhagen congress, as earlier it had escaped those of the ISNTUC, and as a result any exploration of the "essential relationship between internationalism and nationalism" was neglected in favour of the defence of immediate interests. ${ }^{61}$

In all of these cases, international interest was defined as the reinforcement of national organization, which in turn favoured the preservation of the position of the national labour leadership. In most cases, this bolstered the authority of the mainstream social-democratic federations, since, where a choice was made, the revolutionary alternative was excluded. The exception to this rule was the French CGT, as revolutionary

${ }^{58}$ Budapest, Report, p. 26.

${ }^{59}$ See debates, Amsterdam, Bericht, pp. 19-22.

${ }^{60}$ Congrès Socialiste International tenu à Copenhague, 28 août - 3 septembre 1910 (Geneva, 1981 reprint), pp. 362-401.

${ }^{61}$ Ibid., p. 13 (introduction by Georges Haupt). 
syndicalists controlled the national organization. Far from advancing internationalism, the emphasis placed on uniformity and centralization encouraged caution and conservatism. Because it was assumed that whatever reinforced national organization was necessarily beneficial to the international movement, the grey area of conflict between the interests of different national movements remained unresolved.

The ISNTUC inherited various traditions within the international labour and socialist movements: international corporatism, as expressed in the ITS; the First International, with its emphasis on the building-up of national organization and promoting practical international solidarity as part of the same process; Scandinavian labour organization, which showed the possibilities for union of groups where similarities of tradition, culture and outlook prevailed; and the German labour movement, which succeeded in internationalizing its own preoccupations and demands.

Yet in most senses the ISNTUC represented a completely new style of organization: an independent labour organization. Because of this, and because its members were themselves undergoing a process of development, even slow and cautious advances encountered numerous problems. Practical differences arose constantly: language difficulties, clash of cultural expectations, different methods of organization at the most basic level.

Perhaps the greatest obstacle to the development of a more truly internationalist movement was the lack of commitment shown by labour leaders to international activity. As organizations aiming to defend and promote the interests of their members, labour unions saw the need to measure the utility of international organization in terms of concrete benefits. This attitude lowered input into international activity, but also, of course, the benefits to be gained. Legien himself recognized this central weakness of the ISNTUC. His solution was to limit voluntarily the goals of the international organization until all centres were evenly and uniformly developed.

The consequences of this conception of international activity were that it excluded all others. It was a selective internationalism which could only accept those groups which conformed to the uniform standard. This is not to say that the CGT was any more internationalist. The CGT could no more swallow its principles in the name of international unity, for fear of losing its identity back at home, than could the German General Commission. International activity was, in fact, the projection of national interests onto the international level.

The key to international organization was national organization, and, of course, this was interpreted in different ways by different national federations. Legien, for instance, could claim in 1919 that the German labour movement had remained internationalist despite, or even because of, its co-operation with the German government during the war. For Legien, organization was paramount, and the aim of the German labour leader- 
ship in August 1914 was to preserve the labour organization. In this sense, the Burgfrieden was the expression of labour internationalism, since it preserved labour organization. Indeed, Legien resisted efforts to have the secretariat transferred to a neutral country during the war, for this very reason. Seen from this point of view, the conduct of international labour in 1914 was anything but a betrayal of internationalist principles.

That this viewpoint came to dominate the international labour movement poses another question, which is obscured somewhat by the divide between the French syndicalists and the other members of the ISNTUC: the failure of socialism to stop this plainly reformist direction. Søren Federspiel's study of the role of the Danish federation in the ISNTUC has led him to conclude that the early take-over of the International Secretariat by Legien prevented the DsF and other Scandinavian centres from exercising a social-democratic leadership which would have been capable of uniting the various strands of the international labour movement and therefore of creating a more solid international organization. ${ }^{62}$ The participation and subsequent affiliation of the American AFL from 1909 onwards served to consolidate Legien's position and to identify the ISNTUC definitively with social reform forces.

The reason for this largely uncontested direction of the international movement can be found in the membership figures of the ISNTUC. According to figures given in 1913, the mighty German Free Trade Unions headed the ISNTUC's membership list, with 2,530,000 members, followed by the American Federation of Labor, with 1,943,000. If the GFTU membership is added to this sum, it gives a total strength of 5,373,000 for those federations representing the "reformist" or "trade-union" section of the international movement. The rest of the ISNTUC members together had a combined strength of around one and a half million. ${ }^{63}$ Given the importance of membership figures as indicators of the relative strength and position of labour federations, it is easy to see why the ISNTUC became a force for reformism within the international movement.

The growing numerical and financial strength of the German labour movement also had implications for international socialism, since, as others have remarked elsewhere, it meant that the Freie Gewerkschaften represented the most important single group within the Second International. ${ }^{64}$ As a result, the German labour leadership was able to exercise a restraining influence on debates, especially on the mass strike issue and antimilitarism. The ISNTUC reinforced this power and ensured that the

\footnotetext{
${ }^{62}$ Søren Federspiel, "Fagforeningsinternationalen og DsF til 1914", pp. 48-49.

${ }_{63}$ These figures are published in the Report of the Eighth International Conference, 1913, p. 14.

${ }^{64}$ John Moses, for example, makes this point: Trade Unionism in Germany, p. 164.
} 
demands of international socialism, like those of international labour, were tailored along the lines of the German labour movement.

For most of the leaders of the Second International, subordination of trade unions to the political party was the prerequisite for socialist action. Several international socialist congresses, notably those of Zurich in 1893 and London in 1896, stressed this point. In practice, however, trade unions exercised considerable influence in international decision-making. Leninist historiography would later point to this contradiction as a central weakness of the Second International. Others saw the issue from a different perspective. The French CGT, for instance, argued that it was precisely the deference of labour organizations to socialist parties which undermined the revolutionary role of the former.

These arguments mask to some extent the fundamental conflict between a class-conscious radicalism, which rejected class collaboration within the context of the nation and logically looked to internationalism, and social reform policies which logically reasoned in the context of the nation to provide answers, in the form of legislation. When the war, and the Russian Revolution, brought out this central contradiction, it was presented in terms of a straight choice, causing national and international movements to be split asunder. 